\title{
Tin Sulfide Nanoparticle Synthesis from Waste Waters
}

\author{
Jitender Gaur $^{1,2,3^{*}}$, Shilpa Jain ${ }^{1,2,3}$, Suresh Chand ${ }^{3}$, Narender Kumar Kaushik ${ }^{1^{*}}$ \\ ${ }^{1}$ Department of Chemistry, University of Delhi, New Delhi, India \\ ${ }^{2} \mathrm{~J}$ \& S Research and Innovations, New Delhi, India \\ ${ }^{3}$ Physics of Energy Harvesting, CSIR-National Physical Laboratory, New Delhi, India \\ Email: "jitender.jnsri@gmail.com, ${ }^{*}$ narenderkumar_kaushik@yahoo.co.in
}

Received November 20, 2013; revised December 25, 2013; accepted January 5, 2014

Copyright (C) 2014 Jitender Gaur et al. This is an open access article distributed under the Creative Commons Attribution License, which permits unrestricted use, distribution, and reproduction in any medium, provided the original work is properly cited. In accordance of the Creative Commons Attribution License all Copyrights (c) 2014 are reserved for SCIRP and the owner of the intellectual property Jitender Gaur et al. All Copyright (C) 2014 are guarded by law and by SCIRP as a guardian.

\section{ABSTRACT}

Tin and its derivatives are extensively used in modern technology tools which lead requirement for development of green methods for its waste management and profitable recycling. Presence of tin in water bodies causes enormous environmental concern due to its acute toxicity to living beings. We demonstrate a simple and zero emission process for extraction of tin ions from aqueous solution using dithiocarbamate-based copolymer and its single step quantitative recovery and transformation into SnS nanoparticles. The polymer shows high metal extraction capacity, $1.06 \mathrm{~g} \mathrm{SnCl} 2$ per gram of polymer. The polymer metal composite and $\mathrm{SnS}$ nanoparticles are analyzed using TEM, FTIR, XRD spectroscopy techniques. The FTIR shows formation of Sn-S bonding in the polymer metal composite. This study has implication for cost effective and green approach for purification of water and waste management.

\section{KEYWORDS}

\section{Tin Sulfide Nanoparticles; Metal Extraction; Green Chemistry; Hydrothermal Synthesis; Water Purification}

\section{Introduction}

Tin is a high value metal and its compounds are also used in many modern and conventional industrial processes such as lithography, alloys for electronic circuits, reaction catalysis, anti corrosion coating agent, dopant for electrode of modern solar cells [1-7]. The opto-electronic properties of the nanomaterials of tin are adding-in to its industrial demand. The extensive industrial use leads to problems such as leaching of metal in waste water streams [8-11]. This calls for the requirement for waste disposal and efficient recycling of expensive metal and its compounds. Ever since the industrial revolution, several approaches have been developed to address such requirements, for example, electrochemical extraction, sedimentation, co-precipitation etc. [12-16]. However, some of these techniques require expensive equipments and others are inefficient in extraction and most of these do not give high value end product. Therefore, the general in-

\footnotetext{
"Corresponding author.
}

dustrial setups consider waste disposal as a government imposed auxiliary setup, rather than as a productive secondary setup. So a new removal and extraction technique is required which can efficiently remove metal from the aqueous streams and recover the same in some high value final product [17]. The dithiocarbamate (DTC) based polymers are known for high metal extraction potential [14,18-21]. They form chemical bonds via M-S (DTC) with metals in almost all oxidation states [14,18-21]. Also the dithiocarbamates and related molecules such as xanthates are known to produce metal sulfide nanoparticles in various morphologies such as rods, belts, spherical particles, etc. via thermal decomposition under specific reaction conditions [22-28]. Herein we present a simple and efficient green process for extraction of tin from aqueous medium using a DTC-based polymer $\mathrm{P}_{\mathrm{A} 1}$ and recovery of tin as tin sulfide nanoparticles via thermal decomposition of the $\mathrm{Sn}-\mathrm{P}_{\mathrm{A} 1}$ extract. We used the potential of the dithiocarbamate-based copolymer to extract tin chloride through chemical bonding, thereby transforming it into tin sulfide nanoparticles. 


\section{Experimental}

\subsection{Materials and Instruments}

All chemicals were purchased from Sigma-Aldrich, Germany. FTIR spectra of all the molecules were recorded in $\mathrm{KBr}$ pellets on a Perkin-Elmer spectrum 2000 FTIR spectrometer. Elementar Analysensysteme Gmbh Vario El-III instrument was used for CHNS elemental analysis. TG/DTG curves were simultaneously recorded on PerkinElmer Model TGA-7, USA, under a nitrogen atmosphere at a heating rate of $10^{\circ} \mathrm{C} \cdot \mathrm{min}^{-1}$ from $20^{\circ} \mathrm{C}$ to $800^{\circ} \mathrm{C}$. Transmission electron microscope (TEM) was recorded on Tecnai G2 F30 STWIN. Sample for TEM of the polymer was prepared by suspending $\mathrm{P}_{\mathrm{A} 1}$ in methanol by using ultrasonication at $45 \mathrm{kHz}$ for $15 \mathrm{~min}$ and loading them onto the copper grids for TEM.

\subsection{Synthesis of the Polymer and Tin Chloride Extraction Process}

The dithiocarbamate based polymer $\mathrm{P}_{\mathrm{A} 1}$ was synthesized as described in the literature [14].

$100 \mathrm{mg} \mathrm{P}_{\mathrm{A} 1}$ was soaked with slow stirring in $100 \mathrm{ml}$ water for about $1 \mathrm{hrs}$ at room temperature. $10 \mathrm{mM}$ solution stock solution of tin chloride was prepared by mixing $2.25 \mathrm{~g} \mathrm{SnCl}_{2} \cdot 2 \mathrm{H}_{2} \mathrm{O}$ in $1000 \mathrm{ml}$ water. After soaking the $\mathrm{P}_{\mathrm{A} 1}$ in water, $100 \mathrm{ml}$ of the stock solution was added to the $\mathrm{P}_{\mathrm{A} 1}$ slurry followed by stirring for 2 hrs. Then it was filtered to extract the Sn- $\mathrm{P}_{\mathrm{A} 1}$ composite. It was characterized by FTIR, XRD and TEM with EDX. The filtrate was analysed for the concentration of Sn using atomic absorption spectroscopy. The amount of metal salt (in grams) absorbed by $1 \mathrm{~g}$ of $\mathrm{P}_{\mathrm{A} 1}$ is stated as the maximum loading capacity (MLC) of $\mathrm{P}_{\mathrm{A} 1}$. This is calculated by following formula:

$$
\text { MLC }
$$

$=\underline{\text { (grams of metal salt taken }- \text { grams of metal salt remained) }}$ (grams of $\mathrm{P}_{\mathrm{A} 1}$ taken)

\subsection{Synthesis of Tin Sulfide Nanoparticles}

The $10 \mathrm{mg}$ filtered Sn- $\mathrm{P}_{\mathrm{A} 1}$ composite was poured into a $25 \mathrm{ml}$ TEFLON lined stainless steel hydrothermal bomb and approximately $15 \mathrm{ml}$ water was added to it. The mixture was vigorously shaken using a $45 \mathrm{kHz}$ ultrasonicator for $5 \mathrm{~min}$ at room temperature. Than the hydrothermal bomb was sealed tightened using its attachments and placed in an oven for $10 \mathrm{hrs}$ at $125^{\circ} \mathrm{C}$. After $10 \mathrm{hrs}$ heating the hydrothermal bomb was allowed to cool naturally. Then the product was extracted by centrifugation at 10,000 rpm and washed several times with water. The product was dried by keeping it for a week in vacuum desiccator. The product was analyzed using XRD and TEM imaging with EDS.

\section{Results and Discussion}

Figure 1(a) shows highly porous structure of $\mathrm{P}_{\mathrm{A} 1}$ which gives it high surface area for metal ligation. This allows $\mathrm{P}_{\mathrm{A} 1}$ to extract large amount of tin from the aqueous solution. Figure 1(b) shows dark patches of Sn bonded with the $\mathrm{P}_{\mathrm{A} 1}$ all over the polymer surface.

This illustrates the high potential of the metal absorption by the $\mathrm{P}_{\mathrm{A} 1}$. The EDS (Figure 1(c)) of a selected area on the Sn- $\mathrm{P}_{\mathrm{A} 1}$ composite shows highest concentration of $\mathrm{Sn}$ in the composite among all the elements present in it. There are peaks with respect to the $\mathrm{Cu}$ which are due to the copper grid used for the TEM imaging. The Sn- $\mathrm{P}_{\mathrm{A} 1}$ composite was also analyzed by atomic absorption spectroscopy (AAS) and CHNS elemental analysis (Table 1)
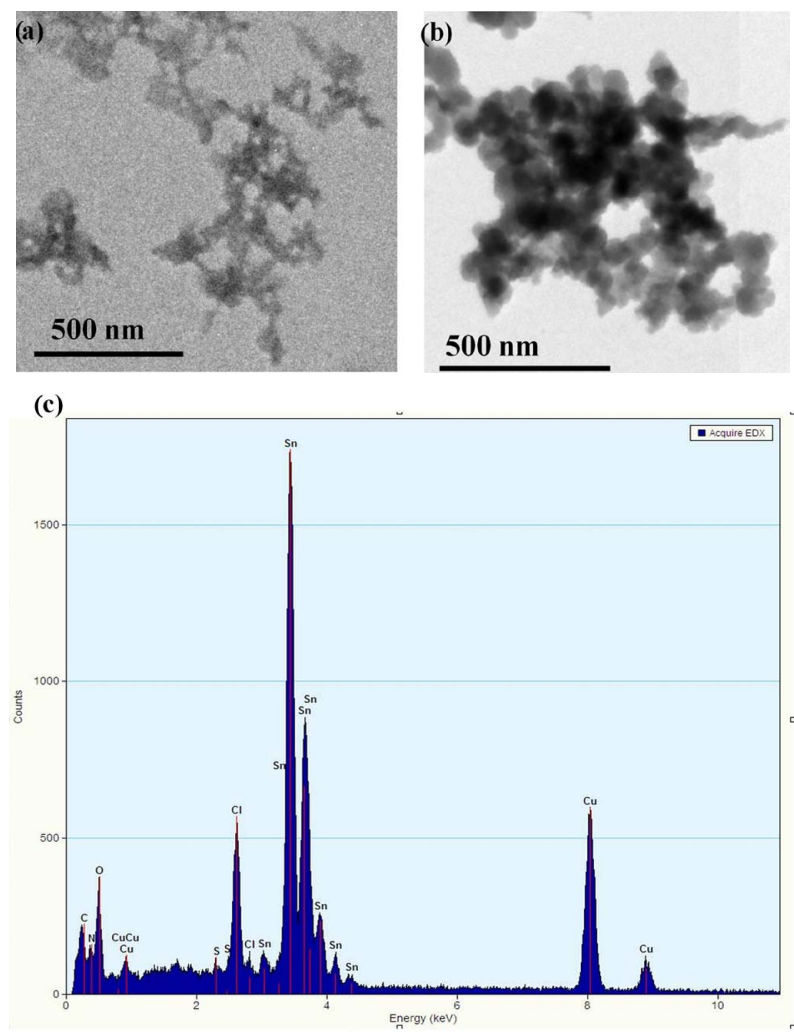

Figure 1. (a) TEM image of $\mathbf{P}_{\mathrm{A} 1}$ showing its porous structure; (b) TEM image of Sn-P $\mathrm{P}_{\mathrm{A} 1}$ composite showing large amount of $\mathrm{Sn}$ bonded with the $\mathrm{P}_{\mathrm{A} 1}$ all over its surface; (c) EDS of a selected area on the Sn-P $P_{A 1}$ composite showing amount of Sn attached with the $P_{\mathrm{A} 1}$.

Table 1. CHNS elemental analysis of $\mathbf{P}_{\mathrm{A} 1}$ and Sn-P $\mathbf{P}_{\mathrm{A} 1}$ composite.

\begin{tabular}{ccccc}
\hline & $\% \mathrm{C}$ & $\% \mathrm{H}$ & $\% \mathrm{~N}$ & $\% \mathrm{~S}$ \\
\hline $\begin{array}{c}\text { Calculated } \\
\mathrm{P}_{\mathrm{A} 1}\end{array}$ & 23.077 & 2.885 & 35.897 & 30.769 \\
$\begin{array}{c}\text { Observed } \\
\mathrm{P}_{\mathrm{A} 1}\end{array}$ & 22.181 & 2.922 & 33.743 & 32.271 \\
$\begin{array}{c}\text { Observed } \\
\text { Sn-P }\end{array}$ & 11.728 & 1.57 & 18.884 & 16.052 \\
\hline
\end{tabular}


to determine the concentration of $\mathrm{Sn}$ in the composite. The results of AAS shows about 32.6\% Sn (w/w) in the Sn- $\mathrm{P}_{\mathrm{A} 1}$ composite. Also the analysis of the filtrate showed significant removal of $\mathrm{Sn}$ as the concentration of Sn lowered from $10 \mathrm{mM}$ to $4.4 \mathrm{mM}$ by $100 \mathrm{mg} \mathrm{P}_{\mathrm{A} 1}$. This means $100 \mathrm{mg} \mathrm{P}_{\mathrm{A} 1}$ extracted 56\% of the tin chloride from the water in single wash i.e., $100 \mathrm{mg}$ bonded with 106.2 mg $\mathrm{SnCl}_{2}$. This gives MLC for the $\mathrm{P}_{\mathrm{A} 1} 1.06 \mathrm{~g} / \mathrm{g}$ of $\mathrm{P}_{\mathrm{A} 1}$. This value is one of its highest performance when compared to the MLC with other heavy metals. [14] The CHNS elemental analysis of the $\mathrm{P}_{\mathrm{A} 1}$ and $\mathrm{Sn}-\mathrm{P}_{\mathrm{A} 1}$ also suggests about $51.8 \%(\mathrm{w} / \mathrm{w})$ of $\mathrm{SnCl}_{2}$ in the $\mathrm{Sn}-\mathrm{P}_{\mathrm{A} 1}$. This gives $32.4 \%(\mathrm{w} / \mathrm{w})$ of $\mathrm{Sn}$ in $\mathrm{Sn}-\mathrm{P}_{\mathrm{A} 1}$, which is in good agreement with the AAS results.

The filtrate was treated with another set of $100 \mathrm{mg} \mathrm{P}_{\mathrm{A} 1}$ for complete recovery of the tin ions present in the solution. The AAS results of the second cycle showed less than $0.01 \mathrm{mM}$ concentration left in the solution. Thus achieving more than $99.9 \%$ recovery of the tin ions from the solution.

Figure 2 shows powder XRD of the polymer (black color) having a broad peak at $2 \theta=35.8^{\circ}[29,30]$. As per the Scherrer equation the broad peak width is inversely proportional to crystallite size [31]. This is in agreement with the high porosity of the polymer structure as seen in its TEM. The XRD pattern of the Sn- $\mathrm{P}_{\mathrm{A} 1}$ composite has dual character of the $\mathrm{P}_{\mathrm{A} 1}$ and the $\mathrm{Sn}$ bonded with the $\mathrm{P}_{\mathrm{A} 1}$. The new peaks in the XRD pattern of Sn- $\mathrm{P}_{\mathrm{A} 1}$ composite show resemblance with that of the $\mathrm{SnS}$ and $\mathrm{SnS}_{2}$. This indicates the ligation of DTC groups present in the $\mathrm{P}_{\mathrm{A} 1}$ with the Sn [28-30].

The FTIR of the $\mathrm{P}_{\mathrm{A} 1}$ (Table 2) shows characteristic bands with respect to the dithiocarbamate, thiourea and hydrazone functional groups along with the imine bonds. The Sn- $\mathrm{P}_{\mathrm{A} 1}$ composite shows blue shift in the bands of $\mathrm{C}=\mathrm{N}, \mathrm{C}=\mathrm{S}, \mathrm{N}-\mathrm{H}$ and $\mathrm{N}-\mathrm{N}$ this is attributed to the ligation with of lone pair of electrons of $\mathrm{N}$ atom of $\mathrm{C}=\mathrm{N}$ and $\mathrm{S}$ atom of $\mathrm{C}=\mathrm{S}$ which enhances the bond strength of these bonds. Whereas the characteristic band and shoulder of the dithiocarbamate bonds at $1000 \mathrm{~cm}^{-1}$ and $925 \mathrm{~cm}^{-1}$, respectively shows significant changes as the shoulder is absent in the Sn- $\mathrm{P}_{\mathrm{A} 1}$ composite. Also the asymmetric stretching band shows a blue shift. This indicates bidentate ligation along with other multiple modes of ligation of $\mathrm{S}$ with the Sn [14,18,19,32].

The TG/DTA of the $\mathrm{P}_{\mathrm{A} 1}$ shows its thermal degradation starts at $140^{\circ} \mathrm{C}$ under $\mathrm{N}_{2}$ atmosphere [14]. However under high pressure in hydrothermal process this degradation would folow different mechanism. It is observed that hydrothermal treatment at $125^{\circ} \mathrm{C}$ gives enough temperature and pressure for cleavage of polymer and formation of tin sulfide. This treatment of the $\mathrm{Sn}-\mathrm{P}_{\mathrm{A} 1}$ composite gives $\mathrm{SnS}$ nanoparticles which may be seen in the SEM image (Figure 3(a)). The nanoparticles are homogenous

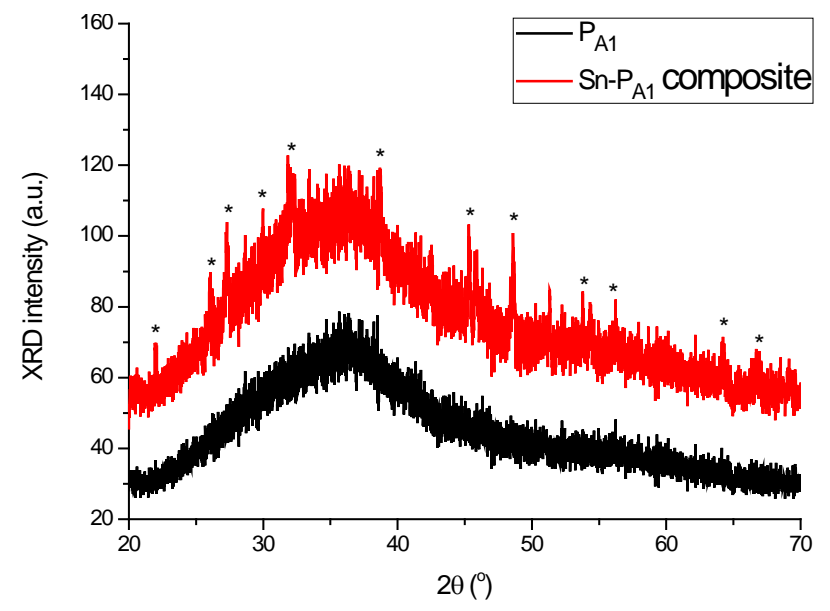

Figure 2. Powder-XRD of $\mathbf{P}_{\mathrm{A} 1}$ and Sn-P $\mathbf{P}_{\mathrm{A} 1}$ composite, the stared peaks are from $\mathrm{Sn}$ bonded with the polymer.

Table 2. FTIR observation table for $\mathbf{P}_{\mathrm{A} 1}$ and Sn-P $\mathbf{P}_{\mathrm{A} 1}$ composite.

\begin{tabular}{cccccc}
\hline Molecules & $v(\mathrm{~N}-\mathrm{H})$ & $v(\mathrm{C}=\mathrm{N})$ & $v(\mathrm{~N}-\mathrm{N})$ & $v(\mathrm{C}=\mathrm{S})$ & $v(\mathrm{~S}=\mathrm{C}-\mathrm{S})$ \\
\hline \multicolumn{7}{c}{$v \cdot \mathrm{cm}^{-1}$ (wavenumber) } \\
$\mathrm{P}_{\mathrm{A} 1}$ & 1600 & 1546 & 1142 & 1050 & $\begin{array}{c}\text { (as, b) } 1000 \\
\text { (ss, sh) } 925\end{array}$ \\
Sn- $\mathrm{P}_{\mathrm{A} 1}$ & 1620 & 1560 & 1180 & 1090 & (as) 1050 \\
\hline
\end{tabular}

as = antisymetric stretch, ss = symmetric stretch, $\mathrm{sh}=$ shoulder, $\mathrm{b}=$ broad as = antisymetric stretch, $\mathrm{ss}=$ symmetric stretch, $\mathrm{sh}=$ shoulder, $\mathrm{b}=$ broad.
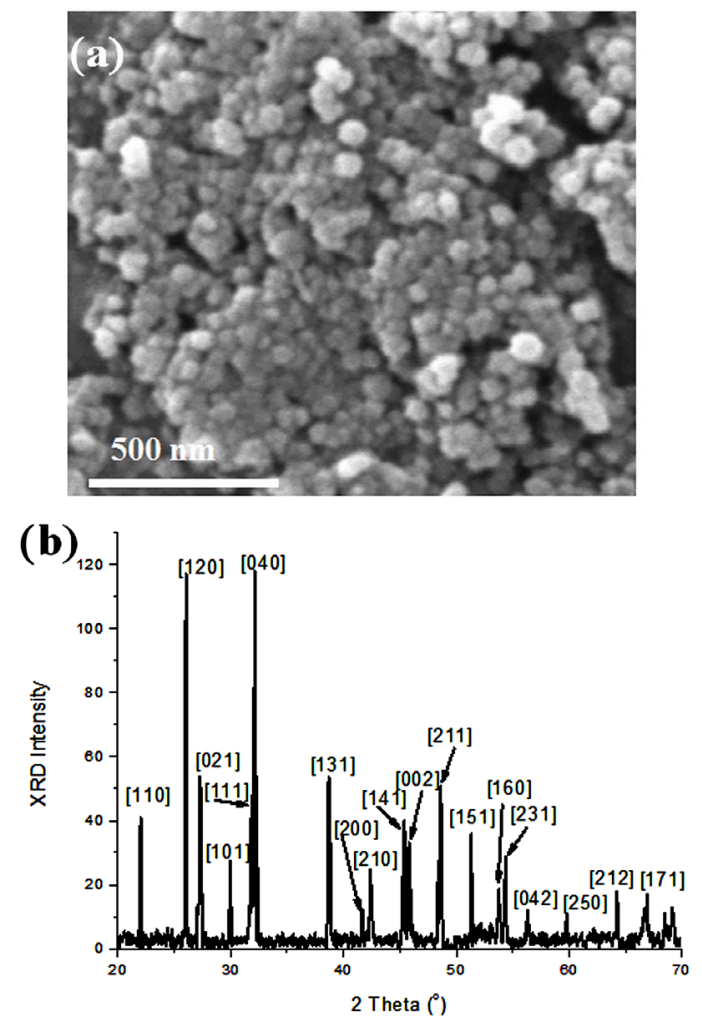

Figure 3. SEM image of SnS synthesized from Sn-P ${ }_{\mathrm{A} 1}$ composite via hydrothermal treatment. 
in spherical shape with particle size $<100 \mathrm{~nm}$. The XRD pattern (Figure 3(b)) of the SnS nanoparticles shows various peaks corresponding to the orthorhomic crystalline phase of the SnS which are in good agreement with the literature values (JCPDS 39-354).

The hydrothermal treatment cleaves the polymer into small water soluble fragments and $\mathrm{SnS}$ nanoparticles were collected as precipitates with isolated yield of $97.2 \%$. The washings of the experiment was analysed by spot test for various organic functional groups. These experiments show presence of thiocynide and hydrazones functional groups. Further analysis of the washings are still going on as we would like to find some meaningful treatment of this by product of the reaction. However the synthesis of the SnS nanoparticles was emission free as no byproducts were allowed to leach in the environment (major advantage of closed vessel hydrothermal processes).

\section{Conclusion}

We successfully demonstrated a simple method for the purification of industrial waste water stream having heavy metal impurities. The tin chloride was efficiently extracted by the polymer at a high metal loading capacity of $1.06 \mathrm{~g} / \mathrm{g}$ of the polymer. Moreover, the sensitivity of the polymer was also quite high for the ultra low concentration of the tin chloride as in the second cycle using another set of pure polymer recovered above $99.9 \%$ of the tin metal ions. The major advantage of this process is the conversion of the waste metal ions into highly useful SnS nanoparticles through a zero emission process. The hydrothermal processes are known for their energy efficiency and green aspects and hence the present work has a high value for industrial pollution and waste management works. The low economic cost of production of the $\mathrm{P}_{\mathrm{A} 1}$ and the use of simple instruments such as autoclaves make this process eligible for futuristic industrial applications.

\section{Acknowledgements}

The authors gratefully acknowledge the financial support from J \& S Research and Innovations, New Delhi, India and University of Delhi, New Delhi, India. J. G is also thankful to DST, Govt. of India, for providing financial support under the India-UK joint initiative project entitled "Advancing the efficiency and production potential of excitonic solar cells (APEX)".

\section{REFERENCES}

[1] Y. Yu, L. Gu, C. Zhu, P. A. van Aken and J. Maier, “Tin Nanoparticles Encapsulated in Porous Multichannel Carbon Microtubes: Preparation by Single-Nozzle Electrospinning and Application as Anode Material for HighPerformance Li-Based Batteries,” Journal of the Ameri- can Chemical Society, Vol. 131, No. 44, 2009, pp 1598415985. http://dx.doi.org/10.1021/ja906261c

[2] P. J. Hotchkiss, S. C. Jones, S. A. Paniagua, A. Sharma, B. Kippelen, N. R. Armstrong and S. R. Marder, "The Modification of Indium Tin Oxide with Phosphonic Acids: Mechanism of Binding, Tuning of Surface Properties, and Potential for Use in Organic Electronic Applications,” Accounts of Chemical Research, Vol. 45, No. 3, 2012, pp. 337-346. http://dx.doi.org/10.1021/ar200119g

[3] M. Planells, A. Abate, D. J. Hollman, S. D. Stranks, V. Bharti, J. Gaur, D. Mohanty, S. Chand, H. J. Snaith and N. Robertson, "Diacetylene Bridged Triphenylamines as Hole Transport Materials for Solid State dye Sensitized Solar Cells," Journal of Materials Chemistry A, Vol. 1, No. 23, 2013, pp. 6949-6960.

http://dx.doi.org/10.1039/c3ta11417a

[4] W. Hamd, M. Chavarot-Kerlidou, J. Fize, G. Muller, A. Leyris, M. Matheron, E. Courtin, M. Fontecave, C. Sanchez, V. Artero and C. Laberty-Robert, "Dye-sensitized Nanostructured Crystalline Mesoporous Tin-Doped Indium oxide Films with Tunable Thickness for Photoelectrochemical Applications," Journal of Materials Chemistry A, Vol. 1, No. 28, 2013, pp. 8217-8225. http://dx.doi.org/10.1039/c3ta10728k

[5] E. Kim, D. M. Gordon, W. Schmid and G. M. Whitesides, "Tin- and Indium-Mediated Allylation in Aqueous Media: Application to Unprotected Carbohydrates,” The Journal of Organic Chemistry, Vol. 58, No. 20, 1993, pp 55005507. http://dx.doi.org/10.1021/jo00072a038

[6] F. Chen, B. Mecheri, A. D’Epifanio, E. Traversa and S. Licoccia, "Development of Nafion/Tin Oxide Composite MEA for DMFC Applications,” Fuel Cells, Vol. 10, No. 5, 2010, pp. 790-797. http://dx.doi.org/10.1002/fuce.200900179

[7] H. Berndt, I. Mönnicha, B. Lücke and M. Menzel, “Tin Promoted Palladium Catalysts for Nitrate Removal from Drinking Water," Applied Catalysis B: Environmental Vol. 30, No. 1-2, 2001, pp. 111-122. http://dx.doi.org/10.1016/S0926-3373(00)00225-3

[8] K. A. Winship, “Toxicity of Tin and Its Compounds,” Adverse Drug Reactions and Acute Poisoning Reviews, Vol. 7, No. 1, 1988, pp. 19-38.

[9] M. R. Krigman and A. P. Silverman, "General Toxicology of Tin and its Organic Compounds," Neurotoxicology, Vol. 5, No. 2, 1984, pp. 129-139.

[10] K. Nagano, T. Nishizawa, Y. Umeda, T. Kasai, T. Noguchi, K. Gotoh, N. Ikawa, Y. Eitaki, Y. Kawasumi, T. Yamauchi, H. Arito and S. Fukushima, "Inhalation Carcinogenicity and Chronic Toxicity of Indium-tin Oxide in Rats and Mice,” Journal of Occupational Health, Vol. 53, No. 3, 2011, pp. 175-187.

http://dx.doi.org/10.1539/joh.10-0057-OA

[11] C. I. Yoo, Y. Kim, K. S. Jeong, C. S. Sim, Nari Choy, J. Kim, J. B. Eum, Y. Nakajima, Y. Endo and Y. J. Kim, “A Case of Acute Organotin Poisoning,” Journal of Occupational Health, Vol. 49, No. 4, 2007, pp. 305-310. http://dx.doi.org/10.1539/joh.49.305

[12] H. Shin, S. N. Srivastava and D. N. Ruzic, “Tin Removal from Extreme Ultraviolet Collector Optics by Inductively Coupled Plasma Reactive Ion Etching," Journal of Vac- 
uum Science \& Technology A, Vol. 26, No. 3, 2008, pp. 389-398. http://dx.doi.org/10.1116/1.2899332

[13] A. S. Sheoran and V. Sheoran, "Heavy Metal Removal Mechanism of Acid Mine Drainage in Wetlands: A Critical Review,” Minerals Engineering, Vol. 19, No. 2, 2006, pp: 105-116.

http://dx.doi.org/10.1016/j.mineng.2005.08.006

[14] J. Gaur, S. Jain, R. Bhatia, A. Lal and N. K. Kaushik "Synthesis and Characterization of a Novel Copolymer of Glyoxal Dihydrazone and Glyoxal Dihydrazone bis(dithiocarbamate) and Application in Heavy Metal Ion Removal from Water," Journal of Thermal Analysis and Calorimetry, Vol. 112, No. 2, 2013, pp. 1137-1143. http://dx.doi.org/10.1007/s10973-013-3136-x

[15] J.-C. Park, “The Removal of Tin from ITO-scrap Using Molten NaOH," Bulletin of the Korean Chemical Society, Vol. 29, No. 1, 2008, pp. 255-256.

http://dx.doi.org/10.5012/bkcs.2008.29.1.255

[16] N. A. Khan, Z. Hasan and S. H. Jhung, “Adsorptive Removal of Hazardous Materials Using Metal-Organic Frameworks (MOFs): A Review," Journal of Hazardous Materials, Vol. 244-245, 2013; pp. 444-456. http://dx.doi.org/10.1016/j.jhazmat.2012.11.011

[17] V. Bharti, S. Jain, J. Gaur, A. Sonania, D. Mohanty, G. D Sharma and S. Chand, "Sustainable Organic Polymer Solar Cells Using $\mathrm{TiO}_{2}$ Derived From Automobile Paint Sludge,” Physics of Semiconductor Devices, Springer International Publishing, Switzerland, 2014, pp. 395-397.

[18] S. P. Huang, K. J. Franz, E. H. Arnold, J. Devenyi and R. H. Fish, "Polymer Pendant Ligand Chemistry-5. The Selective and Competitive Removal of $\mathrm{Ag}^{+}, \mathrm{Hg}^{2+}, \mathrm{Cu}^{2+}$, $\mathrm{Pb}^{2+}$ and $\mathrm{Cd}^{2+}$ ions from Aqueous Solution Utilizing a nSulfonylethylenebis(Dithiocarbamate) Ligand Anchored on Macroporous Polystyrene-Divinylbenzene Beads,” Polyhedron, Vol. 15, No, 23, 1996, pp. 4241-4254. http://dx.doi.org/10.1016/0277-5387(96)00171-4

[19] M. Tabakci, S. Erdemir and M. Yilmaz, "Preparation, Characterization of Cellulose-Grafted with Calix[4]arene Polymers for the Adsorption of Heavy Metals and Dichromate Anions," Journal of Hazardous Materials, Vol. 148, No. 1-2, 2007, pp. 428-435. http://dx.doi.org/10.1016/j.jhazmat.2007.02.057

[20] A. Duran, M. Soylak and S. A. Tuncel, "Poly(Vinyl Pyridine-Poly Ethylene Glycol Methacrylate-Ethylene Glycol Dimethacrylate) Beads for Heavy Metal Removal,” Journal of Hazardous Materials, Vol. 155, No. 1-2, 2008, pp. 114-120. http://dx.doi.org/10.1016/j.jhazmat.2007.11.037

[21] C. Cojocaru, G. Zakrzewska-Trznadel and A. Jaworska, "Removal of Cobalt Ions from Aqueous Solutions by Polymer Assisted Ultrafiltration Using Experimental Design Approach. Part 1: Optimization of Complexation Conditions," Journal of Hazardous Materials, Vol. 169, No. 1-3, 2009, pp. 599-609. http://dx.doi.org/10.1016/j.jhazmat.2009.03.145

[22] D. C. Onwudiwe and P. A. Ajibade, "Thermal Studies of $\mathrm{Zn}(\mathrm{II})$, Cd(II) and Hg(II) Complexes of Some N-AlkylN-Phenyl-Dithiocarbamates," International Journal of Molecular Sciences, Vol. 13, No. 8, 2012, pp. 9502-9513. http://dx.doi.org/10.3390/ijms13089502

[23] R. K. Bhardwaj, H. S Kushwaha, J. Gaur, T. Upreti, V. Gupta, N. Chaudhary, G. D. Sharma, K. Banerjee and S. Chand, "A Green Approach for Direct Growth of CdS Nanoparticles Network in Poly(3-Hexylthiophene-2, 5Diyl) Polymer Film for Hybrid Photovoltaic,” Materials Letters, Vol. 89, 2012, pp. 195-197. http://dx.doi.org/10.1016/j.matlet.2012.08.071

[24] J. Gaur, "Synthesis and Characterization of Complexes of Some Transition Elements with Nitrogen \& Sulphur Containing Ligands,” Ph.D. Thesis, University of Delhi, New Delhi, 2012.

[25] D. C. Menezes, G. M. de Lima, F. A. Carvalho, M. G. Coelho, A. O. Porto, R. Augusti and J. D. Ardisson, "Synthesis of Phase-Pure SnS Particles Employing Dithiocarbamate Organotin(IV) Complexes as Single Source Precursors in Thermal Decomposition Experiments," Applied Organometallic Chemistry, Vol. 24, No. 9, 2010, pp. 650-655. http://dx.doi.org/10.1002/aoc.1663

[26] M. Afzaal, C. L. Rosenberg, M. A. Malik, A. J. P. White and P. O’Brien, "Phosphine Stabilized Copper(I) Complexes of Dithiocarbamates and Xanthates and Their Decomposition Pathways," New Journal of Chemistry, Vol. 35, No. 12, 2011, pp. 2773-2780. http://dx.doi.org/10.1039/c1nj20586b

[27] R. K Bhardwaj, et.al., "In-Situ Growth of CdS Nanorods in PTB7 by Solvothermal Process for Hybrid Organic Inorganic Solar Cell applications,” Physics of Semiconductor Devices, Springer International Publishing, Switzerland, 2014, pp. 331-333.

[28] D. Mohanty, V. Bharti, J. Gaur, R. Bhardwaj, G. D. Sharma and S Chand, "Charge Transport Studies in Pure and CdS Doped PBDTTPD:CdS Nanocomposite for Solar Cell Application,” Physics of Semiconductor Devices, Springer International Publishing, Switzerland, 2014, pp. 323-325.http://dx.doi.org/10.1007/978-3-319-03002-9 81

[29] X.-L. Goua, J. Chena and P. W. Shen, "Synthesis, Characterization and Application of SnSx $(x=1,2)$ Nanoparticles," Materials Chemistry and Physics, Vol. 93, No. 23, 2005, pp. 557-566. http://dx.doi.org/10.1016/j.matchemphys.2005.04.008

[30] H. Peng, L. Jiang, J. Huang and G. Li, "Synthesis of Morphologically Controlled Tin Sulfide Nanostructures,” Journal of Nanoparticle Research, Vol 9, No. 6, 2007, pp. 1163-1166. http://dx.doi.org/10.1007/s11051-006-9208-0

[31] J. I. Langford and A. J. C. Wilson, "Scherrer after Sixty Years: A Survey and Some New Results in the Determination of Crystallite Size,” Journal of Applied Crystallography, Vol. 11, 1978, pp. 102-113. http://dx.doi.org/10.1107/S0021889878012844

[32] J. Granell, M. L. H. Green, V. J. Lowe, S. R. Marder, P. Mountford, G. C. Saunders and N. M. Walker, "Studies on the Synthesis and Electrochemistry of Crown Ether Dithiocarbamates and the Molecular Dynamics of Bis (aza-15-crown-5)Thiuram Disulphide. Crystal Structure of Cobalt tris[(aza-15-crown-5) Dithiocarbamate]," rnal of the Chemical Society, Dalton Transactions, Vol. 2, 1990, pp. 605-614.

http://dx.doi.org/10.1039/dt9900000605 